\title{
3. DOWN TO THE RIVER
}

\author{
People's Memories and Adult Education
}

\begin{abstract}
For Will, the arrival of his grandfather was strange
and exciting. Jack Price turned to him and talked, as the others had not heard him talk since their childhood.

The end of work seemed to have released his spirit.

He read Will's school-books, talked of the politics he remembered, teased both Will and Harry with dialect words

that he had known as a boy but that had gone out of use.
\end{abstract}

- Raymond Williams, Border Country, p. 240

\section{INTRODUCTION}

In the age of the Roman Empire, the shores of the Guadalquivir River traversed a village that we call Rivendel. After then, and until the middle of the past century the river had been the core of the village life. The production system, the culture, the identity and a great part of the history of the place cannot be understood without the river. But at the present time, the memories of the river are becoming lost; the crafts associated with it - from fishing activities to brick factories -are being replaced as the village has become a dormitory town. A collective memory of the river is disappearing, a topic that I will return to again later. Nowadays, few people live directly from the river and, if they do, it is usually in a low-paid jobs at the fringes of the economy. Living from the river is considered an ancient and obsolete way of life totally out of sync with the mainstream driven by globalization and modernization processes.

In this chapter I explore a research project which tries to reconstruct memories of the river through oral history and photographs. This is based on a theoretical framework that contends that in a society when many procedures are standardized, the act of safeguarding popular creativity is a vital element in guaranteeing people's development. In this sense, this chapter attempts to recover the creativity that is present in the traditional crafts arguing that this creativity resides in the community. Crafts which were at the heart of the community feed communal traditions which sustain social solidarity. By recovering and maintaining these traditional crafts, even if only as leisure activities, it may be possible to tap into people's capacity for creativity. Research on memory, craft and knowledge can help with the reconstruction of local 
cultural identities and heritage that can enable people to become protagonists in their own lives and, in doing so, regain some of their own power. This can occur where research is related to adult education in a liberating way that enables individuals and communities to build a critical reflection on their life, cultural heritage and the history of their places.

'Memory work' used to move towards a historical reconstruction of a forgotten community requires a specific type of theoretical and methodological approach. I will describe this through an exploration of an ongoing research project I am involved in with others in Rivendel which uses oral history and photographs. The main tool for the recovery of memory in this project are interviews (using an oral history approach). In this chapter I will explain this process and my research methodology in detail. Before I do so I will first offer an overview of my theoretical positioning. Then based on the material gathered and this theoretical lens I will offer a historical reconstruction of Rivendel based on this research which will lead to reflections on theorizing change and transition.

\section{UNDERSTANDING CRAFT AND CULTURE: THE POLITICS OF RESEARCH AND KNOWLEDGE}

Craftwork is an important part of people's everyday lives as well as their traditions. It creates a shared identity based on their experience derived from their relationships with others and with the surrounding environment. Experience here could be considered as one of the dimensions of adult education and work (Lucio-Villegas, 2015). It is, to a certain degree, the result and the process through which an individual processes knowledge and shares knowledge with others. Furthermore, experience from a Freirean perspective is the basis for a problem-posing education, and it is therefore the source for organizing the processes of teaching and learning to enable people to analyze social change (Freire, 1970). But, sometimes and this is crucial for the research project under discussion - whole swathes of social experience can be lost or rendered invisible in the transition to the 'new economy' (Sennett, 2000).

These experiences can be recovered as educational tools (Lucio-Villegas, 2015, Olesen, 1989). By exploring these experiences it is possible to discern the relationship between adult education, identities, productive work and crafts. According to Gelpi (1990):

The relationships between work and society are not only of economic and social nature. The lack of identity of a community, a country or several countries has consequences concerning the content and the quality of the work. (p. 17)

There is, Gelpi adds, an essential cultural dimension in reflecting on work. Deriving from this, Gelpi talked on the cultures of work, trying to define identities and bonds that people create around it.

In previous social formations the relationships between artisans and their communities were very close. In fact, as Sennett states "in the traditional world of 
the ancient potter or doctor, it was the community who defined the pattern of good work" (2010, p. 38). In Gramscian terms:

The artisan produces pieces of furniture, ploughs, knives, peasant's houses, stoves, etc., always in the same way, according to the traditional taste of one village, province or region. (Manacorda, 1976, p. 273)

The artisan creates whatever they like, but at the same time trying to capture the spirit of people. In short, it seems that these relations among culture, identity, and community life are always present in organizing a part of the quotidian life of people and the system of production.

Today, the quotidian is homogenized to benefit commercial companies which are, largely, dictating people's taste. The work of the artisans is lost, because it is singular and follows guidelines based on the interests of the people, rather than aligning these interests with mass commercial appeal.

In addition, the structure of work has changed. "The time of production is fragmentary and very diverse and the quality of work varies in regard to the content, the development and the aim" (Gelpi, 2004, p. 111). This form of the organization of work abandons some of the characteristics of the craft and craftsmen's work such as the innovative changes in the final product at the end of the production process and the creativity to adapt the final result to the taste and necessities of the communities where the artisans work and live.

Sennett (2000) studied changes in people's daily lives produced by this new organization of work some of these are: the impossibility for many people to coordinate a career due to the constant mobility that means "never for a long time". People are living in a constant state of unpredictability when it comes to organizing their own career and life, in a situation in which their experience is not valued. As Gelpi (2004) stated "All men [sic] have lacked their history even though it is evident that a part of their work's culture is not only still alive but it is essential for production and identity" (p. 46).

An important point to reflect on is that Sennett's argument related to the loss of pride of craftsmanship which, in some ways, means identity. They are people "devoted to doing their best work for the simple fact of doing it well" (Sennett, 2010, p. 32); in fact arguably doing good work is fundamental to the identity of artisans. This entails a specific way of organizing work, and learning and teaching of the craft, and even of living life. A job well done means "curiosity, research and learning from the uncertainty" (Sennett, 2010, p. 66).

Finally, I want to refer to culture. According to Raymond Williams, culture, apart from being a very complicated word (1983, p. 87), is a plural word with diverse meanings. It is not possible to talk about culture, but rather about cultures, and this diversity is not only related to different countries or historic periods but to "social and economic groups within a nation" (Williams, 1983, p. 89).

In the end, culture is a way of life that includes work, intellectual practices or artistic activities among other things. In this direction it is possible to consider the 
activities performed by artisans as a part of the local cultures that are in danger of disappearing through the globalization of production, but not limited to this.

According to Peter Mayo (2010), Gramsci differentiated between 'high' and 'low' culture. Low culture, in some ways, could be related to popular culture or folklore in Gramscian terms. He also considered that research and education may help people to go from folklore and common sense to good sense as a path to grasp the world and analyze it (Manacorda, 1976).

Raymond Williams highlighted the role of criticism in culture (Welton, 1982): as the possibility to think about things beyond collecting data and information without any criteria. To Williams (1983), criticism "developed to ... CULTURE" (p. 83, capital letters in original) with "its positive sense for good or informed judgment" (p. 83). Criticism also means "a definitive practice, in active and complex relations with its whole situation" (Williams, 1983, p. 86). In this sense, it could be said that criticism is the way to develop individual and collective creativity.

My methodological choices try to provide a response to these matters. For that, the selection of interviews as the main tool to collect information is an attempt to encourage informants to also be creative.

\section{METHODOLOGY}

The oral history methodology used for this research drew on a set of interviews and the use of pictures. At this time, nine interviews -60 minutes length each - have been conducted; with eight men and one woman. People interviewed were selected by local people taking part in the research team. The main criteria for selecting interviewers were that they were people who had an ample knowledge of the river and the city and the crafts associated with it. Adhering to these requirements, individuals interviewed included: sailors, fishermen, and a net manufacturer, the owner of a brick factory, and, finally, an older woman with a profound knowledge of the river.

Members of the research team were: adult educators, people working in City Hall, women involved in the womens' resource centre, and adult learners. There were also university students helping in the process of interviews.

Interviews were always audio recorded and, in some cases, video recorded. Interviews were transcribed and analyzed using purposive categories to organize the people's discourses about the river and their quotidian life. For example, it is possible to reconstruct the memories of the people from categories such as: the crafts associated with the river, the feeling of mystery of the river, the role of women, etc.

As an interview is a kind of planned conversation, it is important to say something about the planning itself. The first question presented to the informants always was about and how they first entered into the labor market. This is the crucial point to introduce people to remember about the craft. After this it is possible to return to their life in Rivendel, about the changes in their surrounding world: the family, work, village, river, and so forth. 
Photographs have been useful for presenting moments of the daily life of people and communities. In this sense it is possible to undertake an analysis of the pictures by asking ourselves about the major themes in the culture of the community (Becker, 1986) or, as a most modest goal, to present, in a visual way, the work of artisans and the life in the community. In doing this, it is possible to shift our research orientation from the larger questions to more practical things (e.g. what is important to the people that take these photographs? How did they take the photos? What was the purpose of the photos?).

The sources and intended methodological purposes of these photos are important to note. There are two sources: (a) old photos: professional or mainly domestic pictures. In the case of these photos it is not possible to know the reason the picture was taken, nor the things that pictures does not include (Becker, 1986). (b) Pictures taken by the researchers during the project (e.g. pictures of the river or of the net workshop). These pictures were chosen by local people; either those involved in the Women's Municipal Centre or in the adult education school. The primary idea is to use these pictures as codification - in a Freirean sense - in future work with adult learners. Codification and decoding are two steps in Freire's methodology. In the first, reality in presented to the learners - usually using pictures or drawings. Then, the process of decoding starts and is organized through dialogue to bring to the surface the diverse realities where people live (Freire, 1970). In this sense the use of the pictures could become a powerful element to help people reconstruct their memory of the river. It provides a direct link between research and adult education to reconstruct people's memories of crafts in an adult learning context.

\section{THE RIVER AND THE VILLAGE: A RECONSTRUCTION}

In the middle of the past century two elements arose which changed life in the village and the relationships between the people and the river in Rivendel.

The first one is related to the construction of a great shipyard in the nearby city of Seville. When the shipyard started to recruit workers, they looked for individuals with a basic knowledge of boats. As Seville is not on the coastline, the only people with experience and knowledge were in the surrounding villages which had strong connections to the river. Rivendel was one of these due to their traditional production system based on the river. As recruitment was based on familial ties, a lot of people went to work in the shipyard with the promise of leaving behind the poverty that, at that time, devastated the rural areas of the country. As one of the people that went to work in the shipyard affirmed, he changed his work "because there were no other possibilities, because on the river I earned very little". The loss of the river as a means of commerce also means the end of shipbuilding and other traditional crafts associated with it, such as the boat builders. Historically there were some small shipyards in the village for both building and repairing fishing and transport boats. In fact, some activities are still present but "before we had 50 [fishing boats] and now only 3 remain". 
Combined with poverty, it is possible to view the newly created jobs as a way to distance oneself from the familial work, rife with confusion, as I will examine later on.

A second element that can explain the demise of the production system and the relationships between people and river is the appearance of washing machines. In this case, washing machines are the metaphor of the pollution of the river: "When washing machines arrived, the laundry soap began polluting the river".

At the beginning of the 1960s with the start of the wave of industrialization of the country (and the shipyard is also an example of this) - the pollution of the river more from the industries than by the washing machines, meant the end of fishing as one of the main sources of work and wealth in the village. Industrialization processes also meant the construction of roads and motorways that replaced the commerce previously conducted on the river.

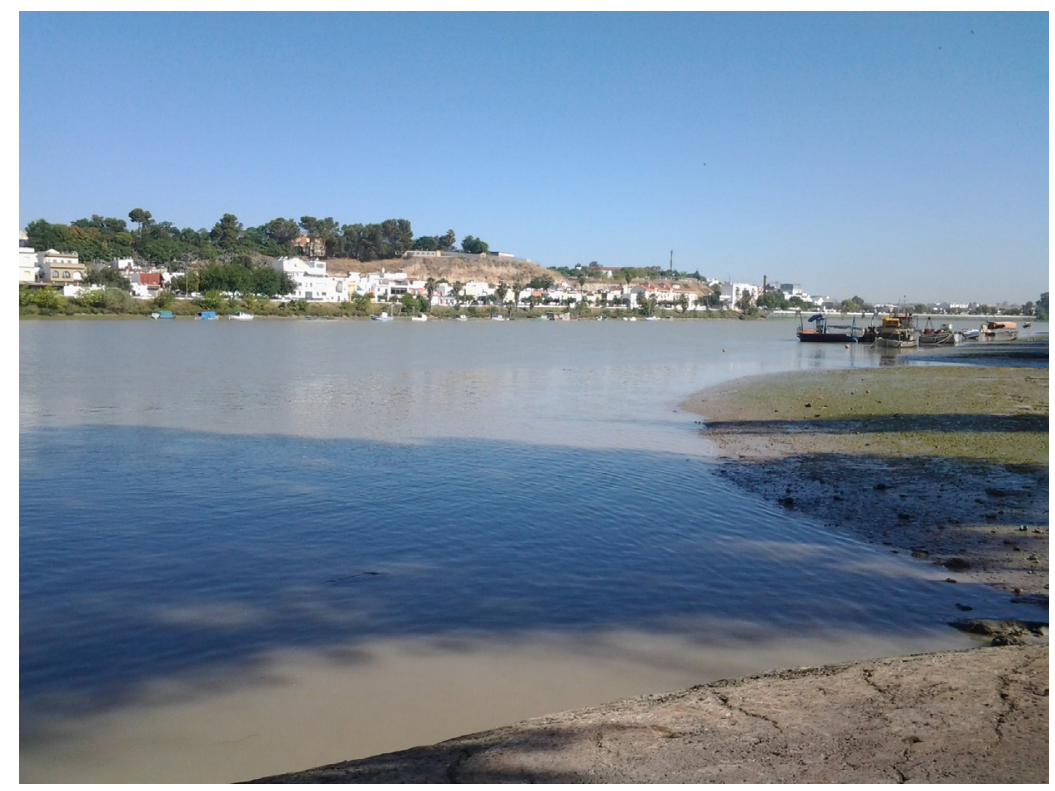

Figure 3.1. River in present time (Guadalquivir River, Spain)

Since the late 1960s, other important changes in the village have occurred, basically related to the shift from a village with a specific and specialized production system into a dormitory town. These changes meant the loss of diverse elements in the daily life of people. The heart of these changes is related to the river and the loss of its importance as the core of life of the village. Perhaps one of the most visible changes is in relation to the river as the way of transporting people and goods from 
one village to another. In the past, the river was a kind of motorway from Rivendel to the mouth of the river at the Atlantic Ocean - "before everything went by boat".

As well as transport; fishing was another important constituent of the production system. There were diverse species of fish, but the most important was the sturgeon. In fact, until 1970 there was a caviar factory in the village. The fishing of sturgeon also led people to the marsh, a place of mystery and legend. It is defined as a natural border between civilization and the unknown. This physical border amplifies the myth of the river as a place outside of the control of people: the river can ruin cows, crops, etc. It also is a place of mystery and disease. This unknown element enabled people to create a magical consciousness about the River that is fatalist and beyond control: "Here you have your thirty cows in winter and then a flood came, and when you could get there [to the place where the cows were], there were no more cows". In short, it could said that "Here began a physical border. From here on down the river it was the marsh [...] of the mosquito diseases".

The end of fishing activities also meant the end of other traditional craft associated with it. For instance, net manufacturing. In fact, today only one net manufacturer remains in Rivendel.

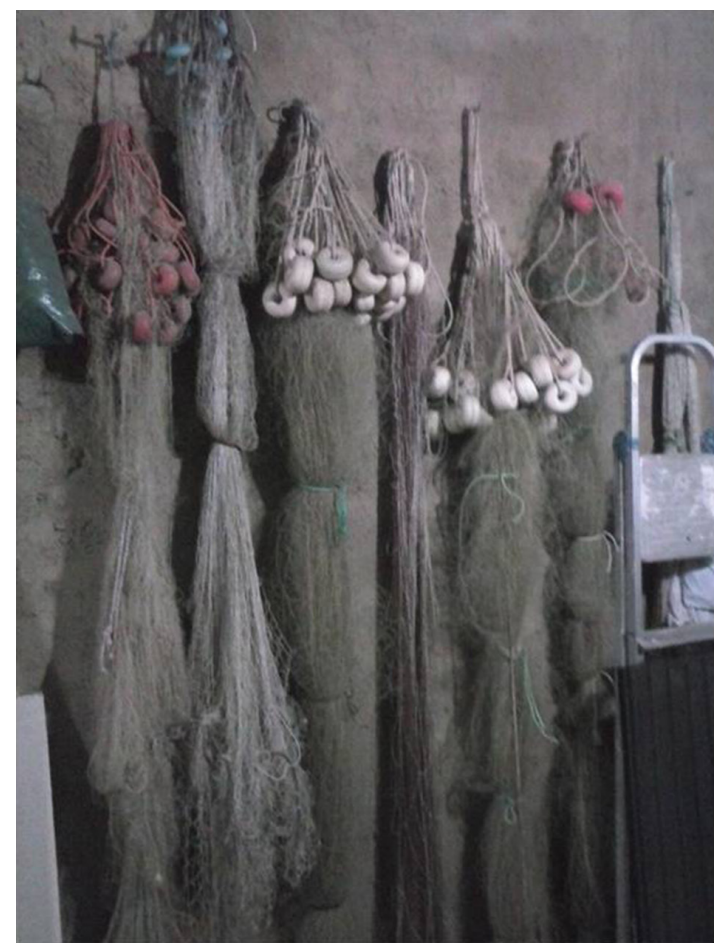

Figure 3.2. Fishing nets 
Traditionally crafts are a kind of heritage passed from father to son - usually the oldest son. In this traditional kinship structure, women are consigned to the domestic space and particular activities associated with the home in this heritage. The production system is based on family relationships which imply the extended family living and working together. This result in a context where social roles are intermixed: the father is the boss; there's no pay for the work, etc. "I went to work with my father. My father was the master and I was the sailor". These complex intermingling of roles resulted in some people having to or feeling the need to escape from this context by looking for a different job in another place, such as the shipyard.

Linked to these crafts, a specific language and way of knowing was created. When crafts - in this sequence from fathers to sons - are vanishing, this specialized language is also lost. The cessation of the craft means that language diversity is disappearing and some words are becoming archaic. "You bring a piece of fabric, a piece of fabric called La Ritana [it is not possible to translate this] for one side. For the other side another piece of fabric and in the middle is the fishing net".

\section{REFLECTION ON THE RESEARCH: GLOBALIZATION \& SOCIAL CHANGE}

We are living in a society which is enmeshed in a unstoppable process of globalization. Local identities are confronted by modernization and the pressures to change traditional ways of life and work in order to increase market profitability (Beck, 1998; Santos, 1998). I have previously studied these processes of change in the case of fishing activities (Lucio-Villegas, 2006). In this research two powerful concepts emerged as important: social change and transition.

Social change can be defined "as the difference observed between the previous and subsequent state of an area of social reality" (Giner, 1985, p. 217). According to Rocher (1985), social change means observable changes, and can be verified within short periods in geographical and socio-cultural areas. It is important to stress that, according to Rocher (1985), change goes beyond purely economic aspects and extends to the way people live, their feelings and their relationships. In short, the concept of social change can allow us to consider the loss of cultural identities that communities - and the people living in them - are suffering in relation to their way of life and the production system associated with it. In order to research social change, Rocher (1985) considers six questions: What is changing? How does the change work? What is the rhythm of the change? What are the elements and determining factors of change? Who are the agents of change? What can we anticipate in the future?

On the other hand, Godelier (1987) spoke of societies in transition. This occurs when they have greater internal and external difficulties in producing traditional economic and social relations. In the process of transition, other forms of economic and social relationships appear. This concept is also linked to the processes of modernization. These processes are associated with the massive incorporation of certain changes as, for instance, in the production system because it is considered 
obsolete. By doing so, the process of modernization is based on curtailing crafts and other forms of economic trade to a kind of marginal niche - in some cases catering to tourism and functioning as anthropological objects of curiosity. Riverdel is an example of these processes of modernization. At present there only is a net manufacturer and the nets are usually used by conservationists for marking the birds and not for fishing. There are no boat builders. It could be said that the crafts are lost, along with the word associated to them.

\section{CONCLUDING DISCUSSION}

This research gives rise to complex findings which have significance for adult education as this concluding discussion illustrates. Firstly, the contradictory feelings that people face in regards to the river. The river is the source of life but, at the same time, it is a dangerous place and it is better not to go there. In some ways it could be affirmed that the production system is dissociated from the quotidian life. The complex view of the river more as an enemy than as a source of work and richness could explain the reason that the inhabitants abandoned their lives on the river. To investigate these beliefs may help people to shift from a magical consciousness to a critical one (Freire, 1970), or in Gramscian terms to move from 'common sense' to 'good sense'. This contribution is clearly related to adult education. In this sense, it can be said that the processes of Popular Education should be rooted in the interest and curiosity of the people and should produce really useful knowledge for individuals and communities. In this case, the really useful knowledge is related to the knowledge of the history and to preserve the present by considering the past. This may also allow people to be situated in their community and society in a path of resistance and transformation.

A second issue is related to the impact of modernization processes. It seems that some of the most profound changes that the village suffered are related to the shift from a rural society to an industrial and urban one. The integration of the artisans working in the shipyard in Seville and in other jobs around the world was a chance for them to position themselves in more secure jobs, increase their salary and, in economic terms, to improve their quality of life.

The challenge here is to determine how to preserve a traditional production system while simultaneously guaranteeing both jobs and quality of life. As well, this is connected to processes of social change that have occurred in the village in the last 60 years. They are - mainly related to industrialization processes - the construction of a shipyard in the city of Seville, or the pollution of the river, as mentioned above.

Another important element is to try to avoid the Manichaeism between global and local; considering the local as good and the global as evil. Robertson (1995, 2012) states that the local means, among other things, a reconstruction of the global. Important connections exist between global and local trends that are derived from mutual influences. In some ways, the local is shaping the global. This occurs within the existence of power relations as the loss of the traditional production system 
can be explained - among other things - by the construction of a shipyard and the pollution of the river, which are global matters related to the expansion of a certain model of development rooted in economy and not in well-being.

Culture is closely linked to language. Subordinate culture is reflected, among other things, in language (Diaz Salazar, 1991). If words are lost, we are losing an important part of this popular culture that, in this case, is represented by a specific and technical oral language. But the most important thing here is that these words are in the collective memory and in the cultural identity of the communities. Preserving these words and the language associated with it is also to preserve the creativity of the community and their identity because words express the world of individuals and communities. And the question here is how to preserve the orality in a society - and in literacy processes - that always reinforces reading and writing? Grammar in this sense is political and linked to dominant culture.

Opposite to this hegemonic project of domination are interesting experiences that combine literacy, memories and craft. One of these is the Currach Project (Reeves, 2010) rooted in Edinburgh that combines environmental issues - the recovery of the Union Canal and the preservation of a singular and traditional boat - the Currach, with literacy processes such as writing, reading and numeracy to build the boat. These kinds of initiatives enable people to be situated in their own reality, to be aware of it and establish ties with other situations. In short, it can be said that they reinforce the ability for people to develop their own creativity that is, in a certain way, a form of recovering the power lost in an educational system and a society based on standardized procedures. Reconstructing our collective memories of the river through oral histories can enable people to regain their local cultural identities and heritage and become protagonists of their life and, in doing so, regain some of their own power.

\section{REFERENCES}

Beck, U. (1998). ¿Qué es la globalización? Barcelona: Paidós.

Becker, H. S. (1986). ¿Dicen la verdad las fotografías? En T. D. Cook y Ch. S. Reichardt (Eds.), Métodos cualitativos y cuantitativos en investigación educativa (pp. 148-170). Madrid: Morata.

Díaz Salazar, R. (1991). El proyecto de Gramsci. Madrid: Anthropos.

Freire, P. (1970). Pedagogy of the oppressed. New York: The Continuum Publishing Company.

Geertz, C. (1987). La interpretación de las culturas. Barcelona: Gedisa.

Gelpi, E. (1990). Educación permanente. Problemas laborales y perspectivas educativas. Madrid: Popular.

Gelpi, E. (2004). Trabajo futuro. La formación como proyecto político. Xàtiva: Edicions del CREC.

Gelpi, E. (2008). El trabajo: utopía cotidiana. Xàtiva: Edicions del CREC.

Giner, S. (1985). Sociología. Barcelona: Península.

Godelier, M. (1987). Introducción: el análisis de los procesos de transición. Revista Internacional de Ciencias Sociales, 114, 5-16.

Gramsci, A. (1974). La formación de los intelectuales. Barcelona: Grijalbo.

Hobsbawm, E. (2001). La era de la revolución, 1789-1848. Barcelona: Critica.

Junta de Andalucía. (2016). Retrieved June 30, 2016, from http://www.juntadeandalucia.es/ institutodeestadisticay cartografia/sima/htm/sm41034.htm 
Käpplinger, B. (2015). Adult education research between field and rhizome- - a bibliometrical analysis of conference programmes of ESREA. European Journal of Research on the Education and Learning of Adults, 6(2), 139-157.

Labov, W. (1983). Modelos sociolingüisticos. Madrid: Cátedra.

Lucio-Villegas, E. (2006). Desarrollo y cambio social en espacios sociales en transformación. Pedagogía Social. Revista Interuniversitaria, 12-13, 119-135.

Lucio-Villegas, E. (2015). Adult education in communities. Approaches from a participatory perspective. Rotterdam, The Netherlands: Sense Publishers.

Manacorda, M. A. (1976). La alternativa pedagógica. Barcelona: Nueva Síntesis.

Mayo, P. (2010). Antonio Gramsci and his relevance for the education of adults. In P. Mayo (Ed.), Gramsci and educational thought (pp. 21-37). Chichester: Wiley-Blackwell.

Olesen, H. S. (1989). Adult education and everyday life. Roskilde: Roskilde University.

Reeves, S. (2010). Construir un Currach. En E. Lucio-Villegas y P. Aparicio (Eds.), El valor de la palabra. Alfabetizaciones, liberaciones y ciudadanias planetarias (pp. 217-231). Xàtiva: Educions del CREC.

Robertson, R. (1995). Glocalisation: Time-space and homogeneity-heterogeneity. En M. Featherstone, S. Lash, y R. Robertson (Eds.), Global modernities (pp. 25-44). London: Sage Publications.

Robertson, R. (2012). Globalisation or glocalisation. The Journal of International Communication, 18(2), 191-208.

Rocher, G. (1985). Introducción a la sociología general. Barcelona: Herder.

Sampedro, J. L. (2003). El río que nos lleva. Barcelona: Destino.

Santos, B. S. (1998). Reinventar a Democracia. Lisboa: Fundação Mário Soares/Gradiva Publicações.

Saramago, J. (2015). Viaje a Portugal. Barcelona: De Bolsillo.

Sennett, R. (2000). La corrosion del carácter. Madrid: Anagrama.

Sennett, R. (2010). El artesano. Madrid: Anagrama.

Welton, M. (1982). Gramsci's contribution to the analysis of public education knowledge. The Journal of Educational Thought, 16(3), 140-149.

Williams, R. (1983). Keywords. Oxford: Oxford University Press.

Williams, R. ([1960] 2013). Border country. Llandibïe: Library of Wales. 